\title{
Gökkuşağı Alabalığı Kökenli Listonella anguillarum İzolatlarının Fenotipik ve Genotipik Karakterizasyonu
}

\author{
Ertan Emek Onuk ${ }^{1}$, Soner Altun², Muhammed Duman², İzzet Burçin Satıcığglu², H. Kaan Müştak ${ }^{3}$ \\ ${ }^{1}$ Ondokuz Mayls Üniversitesi, Veteriner Fakültesi, Su Ürünleri Hastalıklarl Anabilim Dalı, Samsun \\ ${ }^{2}$ Uluda ̈̈ Üniversitesi, Veteriner Fakültesi, Su Ürünleri Hastalıkları Anabilim Dalı, Bursa \\ ${ }^{3}$ Ankara Üniversitesi, Veteriner Fakültesi, Mikrobiyoloji Anabilim Dall, Ankara
}

Geliş Tarihi / Received: 07.11.2018, Kabul Tarihi / Accepted: 23.11.2018

\begin{abstract}
Özet: Bu çalışmada, gökkuşağı alabalıklarından izole edilen altı L. anguillarum izolatı ve bir referans suş fenotipik ve genotipik özellikler açısından incelendi. İzolatların fenotipik özelliklerinin belirlenmesinde klasik mikrobiyolojik testler ve API 20 E strip testi kullanıldı. İzolatların moleküler identifikasyonu amiB genine dayanan L. anguillarum tür spesifik PCR uygulaması ve sonrasında aynı bölgenin sekans analizinin yapılmasıyla gerçekleştirildi. İzolatların dokuz farklı antibiyotiğe karşı antimikrobiyel aktiviteleri disk difüzyon yöntemiyle belirlendi. Ayrıca izolatlar arasındaki olası klonal ilişkiler Rastgele Amplifiye Edilmiş Polimorfik DNA (RAPD) metodu ile ortaya konuldu. API 20 E testlerinde izolatlar arasında $\beta$-Galaktosidaz, arginin dihidrolaz, sitrat, sorbitol, amygdalin ve arabinoz testlerinde farklıklar görülmüştür. Tüm izolatların L. anguillarum spesifik 429 bp'lik bant verdiği saptanmış ve bu sonuç sekans analizi ile doğrulanmıştır. L. anguillarum izolatlarının çalışmada kullanılan dokuz farklı antibiyotiğe karşı değişik düzeyde antimikrobiyal aktiviteye sahip oldukları belirlendi. En yüksek direnç oranı neomisin ve linkomisin'e (\% 100), en düşük direnç oranı ise doksisklin'e (\% 14,2) karşı gözlendi. RAPD analizi sonucunda L. anguillarum izolatları \% 60 benzerlik katsayısına göre bir unique tip ve beş alt türden oluşan bir küme (cluster) içerisinde gruplanmıştır. Bu çalışmanın balık kökenli $L$. anguillarum izolatlarının fenotipik ve genotipik özelliklerinin belirlenmesi ile ilgili ileride yapılacak çalışmalara temel oluşturabileceği düşünülmektedir. Ayrıca elde edilen sonuçlar, balık hastalıklarının tedavisinde uygun antimikrobiyal ajanların seçilmesinin önemini ortaya koymaktadır.
\end{abstract}

Anahtar Kelimeler: Antibiyotik, Genotiplendirme, Gökkuşağı alabalığı, Listonella anguillarum

\section{Phenotypic and Genotypic Characterization of Listonella anguillarum Isolates from Rainbow Trout}

\begin{abstract}
In this study, six L. anguillarum isolates obtained from rainbow trout and one reference strains were examined in terms of phenotypic and genotypic characteristics. Conventional microbiological and API 20E tests were used to determine phenotypic characteristics of isolates. Molecular identification of isolates was carried out by applying the L. anguillarum specific PCR method based on the $a m i B$ gene followed by sequence analysis of the analysis of amplified product with the same primer pairs. Antimicrobial activity of isolates was determined by disk diffusion method against the nine different antibiotics. Additionally, possible clonal relationships between isolates were demonstrated by the RAPD-PCR method. There were differences between strains in terms of $\beta$-galactosidase, arginine dihydrolase, citrate, sorbitol, amygdalin and arabinose tests in API 20E system. In L anguillarum specific PCR assay all of isolates gave the final PCR product of $429 \mathrm{bp}$ and this result was confirmed by sequence analysis. L. anguillarum isolates were found to have different levels of antimicrobial activity against nine different antibiotics used in the study. There was a high incidence of resistance to neomycine and lincomycine (84\%), and a low incidence of resistance to doxycycline (14.2\%). In RAPD method, L. anguillarum isolates were grouped into one unique type and one cluster including five subtypes according to $60 \%$ similarity coefficient index. The present study was considered to may provide a basis for further studies on phenotypic and genotypic characterization of L. anguillarum isolates from fishes. Moreover the present results showed the importance of choosing appropriate antimicrobial agents for treatment of fish diseases.
\end{abstract}

Key words: Antibiotic, Genotyping, Listonella anguillarum, Rainbow trout

\section{Giriş}

Vibriozis çeşitli deniz ve tatlı su balıklarında, çift kabuklu ve eklem bacaklılarda ölümcül hemorajik septisemi ile seyreden ve tüm dünyada hem akua- kültürde hem de larvikültürde önemli ekonomik kayıplara neden olan bir hastalıktır [11]. Hastalığın etkeni olan Vibrio anguillarum başlangıçta Biyotip 1 ve 2 olarak iki biyotipe ayrılmıştır [15]. Ancak, $V$. anguillarum biyotip 2 DNA teknolojisindeki geliş- 
meler sonucunda $V$. ordalii adiyla yeni bir tür olarak yeniden sınıflandırılmıştır [28]. V. anguillarum biyotip 1 ise 5S ribozomal RNA (rRNA) gen dizisi analizine dayanarak Listonella anguillarum olarak yeniden sınıflandırılmıştır [21]. Ancak bazı araştırmac1lar halen $V$. anguillarum ismini kullanmayı tercih etmektedirler [11, 35].

Vibriozis hastalığın neden olduğu ekonomik kayıpların etkili bir şekilde en aza indirilmesi ve uygun kontrol önlemlerinin alınması için $L$. anguillarum'un hızlı, doğru ve güvenilir bir şekilde saptanması önem arz etmektedir. Geleneksel olarak etkenin tanımlanması klinik ve histolojik bulguların yorumlanması, patojenin seçici bir ortamda kültüre edilmesi, morfolojik veya biyokimyasal özelliklerinin ortaya konulması ile yapılmaktadır [11]. Ancak karışık kültürlerden morfolojik ve biyokimyasal olarak L. anguillarum'un identifikasyonunda yanlış sonuçların elde edildiği bildirilmiştir $[3,14$, 20]. Bunun yanında bakteriyel balık patojenlerinin identifikasyonunda API 20E minyatürize test sistemlerinin kullanımının giderek arttığı görülmektedir. Fakat API Web tabanında $V$. anguillarum'un bulunmaması bu sistemin kullanımını sınırlamaktadır [5, 25]. Klasik kültür ve minyatirüze sistemlere dayanan saptama ve tanımlama tekniklerinde yaşanılan bu sınırlamalar, bu yöntemlerin yerine kültürden bağımsız tekniklerin geçmesine veya onlar ile desteklenmelerine neden olmaktadır [5, 9]. Günümüzde L. anguillarum izolatlarının genetik olarak identifikasyonunda $r p o \mathrm{~N}$ geni, $a m i \mathrm{~B}$ geni ve emp $\mathrm{A}$ genini hedef alan spesifik PCR metotları geliştirilmiştir $[13,17,35]$.

Moleküler tiplendirme metotları çevresel ve klinik örneklerden elde edilen izolatlar arasındaki ilişkiyi belirleyen güçlü araçlardır ve etkenlerin ortak bulaş yolları hakkında kanıtlar sağlarlar. Bakteriyel izolatların genetik olarak tiplendirilmesinde restriction fragment length polymorphism, pulsed-field gel electrophoresis (PFGE), RAPD PCR ve repetitive-sequence-based polymerase chain reaction gibi çeşitli moleküler yöntemler kullanılmıștır. Bu metotlardan PFGE'nin bakterilerin tiplendirilmesinde en iyi metot olduğu düşünülmektedir, ancak bu metodun prosesinin zahmetli olması, zaman gerektirmesi ve teknik olarak zor olması çok sayıda örneğin işlenmesinde rutin kullanımda sınırlamaktadır. PCR tabanlı yöntemlerden RAPD PCR yöntemi PFGE ile karșılaştırıldığında hızlı ve uygulaması basit olan yöntemlerdir [6]. RAPD PCR metodu son yıllarda bakteriyel balık patojenleri arasındaki klonal yakınlıkların belirlenmesinde yaygın bir kullanım alanı bulmuştur [18, 23, 26].

Bu çalışma ile ülkemiz su ürünleri sektöründe, özellikle, alabalık işletmelerinde önemli ekonomik kayılara neden olan L. anguillarum izolatlarının fenotipik ve genotipik karakterizasyonunun yapı1mas1, izolatların antimikrobiyal profillerinin ortaya konulması ve izolatlar arası klonal ilişkilerin belirlenmesi amaçlanmıştır.

\section{Materyal ve Metot}

Bakteriyel İzolatlar: Çalışmada Türkiye'nin değişik illerinden izole edilen altı $L$. anguillarum izolatı ve 1 referans suș (ATCC 14181) kullanıldı (Tablo $1)$.

Tablo 1. Çalışmada kullanılan L. anguillarum suşları

\begin{tabular}{ccc}
\hline No & İzolasyon Yeri & İzolasyon Yllı \\
\hline 1 & İzmir & 2012 \\
2 & Kütahya & 2012 \\
3 & Bilecik & 2012 \\
4 & Muğla & 2012 \\
5 & İzmir & 2012 \\
6 & İstanbul & 2012 \\
7 & ATCC 14181 & - \\
\hline
\end{tabular}

İzolatların Fenotipik Özelliklerinin Belirlenmesi: İzolatların Gram morfoloji, oksidasyon-fermentasyon $(\mathrm{O} / \mathrm{F})$, jelatin hidrolizi, sitokram oksidaz, katalaz, \% 0 ve $\% 7, \mathrm{NaCl}$ 'de üreme, 37 ${ }^{\circ} \mathrm{C}$ 'de üreme, indol, metil kırmızısı, voges proskaver (VP) reaksiyonu, arabinoz, inositol, sakkaroz, laktoz, mannitol ve glukoz'dan asit üretimi, vibriostatik ajan (O/129) duyarlılık ve Thiosulfate Citrate Bile Sucrose (TCBS) besiyerindeki koloni morfolojisi konvansiyonel mikrobiyolojik metotlar ile belirlendi. Ek olarak bütün izolatların, API 20E (Biomerieux) hızlı teşhis kiti yönergesine uygun olarak striplere ekimleri yapıld 1 ve $25^{\circ} \mathrm{C}^{\prime}$ de 24 saat inkübe edilerek sonuçlar değerlendirildi.

\section{L. anguillarum Spesifik PCR ve Sekans Ana-}

lizi: Konvansiyonel olarak identifiye edilen $L$. anguillarum izolatları moleküler olarak PCR metodu 
ile doğrulandı. Bu amaçla öncelikle izolatlara ait saf kültürlerden ticari DNA ekstraksiyon kiti (Qiagen, $\mathrm{GmbH}$ ) kullanılarak kromozal DNA'lar elde edildi. L. anguillarum izolatlarının PCR ile moleküler konfirmasyonunda $\mathrm{N}$-acetylmuramoyl-1-alanine amidase enzimini kodlayan $a m i \mathrm{~B}$ genine özgü van-ami 8 (5'-ACATCATCCATTTGTTAC-3) ve 417 (5'-CCTTATCACTATCCAAATTG-3') oligonukleotid primer seti kullanıldı [17]. PCR amplifikasyonunda DEPC-treated water, 1xPCR Buffer, $1.2 \mathrm{mM}$ of $\mathrm{MgCl}_{2}$ her bir dNTP'den $0.2 \mathrm{mM}$, her bir primerden $2 \mu \mathrm{M}, 1.0 \mathrm{U}$ Taq polymerase ve 5 $\mu 1$ template DNA içeren $25 \mu$ l PCR master mix'i oluşturuldu. Oluşturulan karışım $95^{\circ} \mathrm{C}^{\text {' }} \mathrm{de} 10 \mathrm{dk}$ ön denatürasyonu takiben $95^{\circ} \mathrm{C}$ 'de 30 sn denatürasyon, $56^{\circ} \mathrm{C}^{\prime}$ de 30 sn primer bağlanma, $72^{\circ} \mathrm{C}^{\prime}$ de $30 \mathrm{sn}$ uzama olmak üzere 25 siklus ve $72^{\circ} \mathrm{C}^{\text {' }} \mathrm{de} 7 \mathrm{dk}$ final uzama koşullarında amplifikasyon işlemine tabi tutuldu. Sonuçta 429 bp'lik amplifikasyon ürününün görülmesi pozitif olarak değerlendirildi.

Elde edilen 429 bp'lik amplifikasyon ürünlerinin sekans analizi Applied Biosystems 3130 Genetic Analyzer'da aynı primerler kullanılarak çift yönlü olarak yapıldı. Elde edilen sekanslar Blast programı kullanılarak GenBank veri tabanında bulunan mevcut sekanslar ile karşılaştırıldı. İzolatlara ait sekans dizileri GenBank'a yüklenerek kabul numaraları alınd.

İzolatlar Arası Genetik İlişkinin Belirlenmesi: İzolatlar arası klonal ilişkinin belirlenmesinde M13 (5'-GAGGGTGGCGGTTCT-3') primerinin kullanıldığ1 RAPD PCR metodu kullanıldı [32]. Amplifikasyon aşaması Versalovic ve ark. [33] tarafindan bildirilen metodun modifiye edilmesiyle gerçekleştirildi. Bu aşamada DEPC-treated water, $1 \times$ PCR Buffer, $2.5 \mathrm{mM} \mathrm{MgCl}, 200 \mu \mathrm{M}$ her bir dNTP, 1.25 U Taq DNA polimeraz, 25 pmol primer ve $5 \mu \mathrm{l}$ template DNA içeren $25 \mu$ ''lik bir master karışımı oluşturuldu. $\mathrm{Bu}$ karışım $94^{\circ} \mathrm{C}$ 'de $5 \mathrm{dk}$ ön denatürasyonu takiben $94^{\circ} \mathrm{C}^{\circ} \mathrm{de} 1 \mathrm{dk}$ denatürasyon, $40^{\circ} \mathrm{C}^{\text {'de }} 1 \mathrm{dk}$ primer bağlanma, $72^{\circ} \mathrm{C}$ ' de $3 \mathrm{dk}$ uzama olmak üzere 40 siklus ve $72^{\circ} \mathrm{C}$ ' de $7 \mathrm{dk}$ final uzama koşullarında amplifikasyon işlemine tabi tutuldu. Amplifikasyon ürünleri etidium bromid $(2 \mu \mathrm{g} / \mathrm{ml})$ içeren \% 1.5 'luk agaroz jel elektroforezi sonrasında UV transilluminatör ile görüntülendi.

DNA profilleri CHEF-DR ${ }^{\circledR}$ III, Quantity One ${ }^{\circledR}$ yazılımı (Bio-Rad Laboratories, Hercules, CA) ile analiz edildi. Dendrogramları unweighted-pair grup metodu (UPGMA) ile oluşturuldu.

Antimikrobiyal Duyarlılık Testi: Tüm izolatların antimikrobiyal duyarlılıkları Mueller-Hinton agar'da Kirby-Bauer disk difüzyon metodu ile test edildi [7]. Antimikrobiyal duyarlılıkların belirlenmesinde amoksisilin $(25 \mu \mathrm{g})$, doksisiklin $(30 \mu \mathrm{g})$, eritromisin $(15 \mu \mathrm{g})$, gentamisin $(120 \mu \mathrm{g})$, florfenikol $(30 \mu \mathrm{g})$, linkomisin $(2 \mu \mathrm{g})$, neomisin $(10 \mu \mathrm{g})$, oksiytetrasiklin $(30 \mu \mathrm{g})$, ve sulfamethoksazoleazole+trimethoprim $(25 \mu \mathrm{g})$ (Oxoid) diskleri kullanıld1. 24 - 48 saat inkübasyon sonrasında zon çapları ölçülerek kaydedilmiştir.

\section{Bulgular}

İzolatlarının Fenotipik Karakterizasyonu: L. anguillarum izolatlarının TSA besi yerinde $22{ }^{\circ} \mathrm{C}$ ' de 48 saat inkübasyon sonucunda 1-2 mm çapında, yuvarlak, kenarları düz, hafif konveks, kabarık görünümde ve krem renginde, TCBS agarda ise sarı renkte koloniler oluşturduğu belirlendi. API $20 \mathrm{E}$ test sonuçlarına göre izolatlar arasında $\beta$-galaktosidaz (ONPG), arginin dihidrolaz (ADH), sitrat, sorbitol, amygdalin ve arabinoz testleri yönünden farkl1lıklar olduğu belirlendi (Tablo 2). Konvansiyonel mikrobiyolojik testler ile API 20E test sonuçları karşılaştırıldığında L. anguillarum izolatlarının büyük ölçüde benzer olduğu ancak lizin dekarboksilaz (LDC), VP ve sitrat testlerinde farklı sonuçların görüldüğü tespit edildi. Çalışmada kullanılan saha izolatlarının konvansiyonel testler ile belirlenmiş fenotipik özellikleri ve bu özelliklerin diğer araştırmacıların bildirmiş oldukları sonuçlar ile karşılaştırması Tablo 3'de verildi.

Tablo 2. L. anguillarum izolatlarının API 20E hızlı teşhis kiti test sonuçları

\begin{tabular}{lccccccc}
\hline \multirow{2}{*}{ Fenotipik Özellikler } & \multicolumn{7}{c}{ Izolat No } \\
\cline { 2 - 7 } & $\mathbf{1}$ & $\mathbf{2}$ & $\mathbf{3}$ & $\mathbf{4}$ & $\mathbf{5}$ & $\mathbf{6}$ & $\mathbf{7}$ \\
\hline ONGP & + & + & + & - & + & + & + \\
ADH & + & - & + & + & + & + & + \\
LDC & - & - & - & - & - & - & - \\
ODC & - & - & - & - & - & - & - \\
Sitrat Üretimi & - & + & + & + & - & + & - \\
H$_{2} S$ Üretimi & - & - & - & - & - & - & - \\
Ureaz Üretimi & - & - & - & - & - & - & - \\
TDA & - & - & - & - & - & - & - \\
İndol Üretimi & + & + & + & + & + & + & +
\end{tabular}




\begin{tabular}{lccccccc}
\hline \multirow{2}{*}{ Fenotipik Özellikler } & \multicolumn{7}{c}{ Izolat No } \\
\cline { 2 - 7 } & $\mathbf{1}$ & $\mathbf{2}$ & $\mathbf{3}$ & $\mathbf{4}$ & $\mathbf{5}$ & $\mathbf{6}$ & $\mathbf{7}$ \\
\hline VP & + & + & + & + & + & + & + \\
Jelatin Hidroliz & + & + & + & + & + & + & + \\
Glukoz* & + & + & + & + & + & + & + \\
Mannitol* $^{*}$ & + & + & + & + & + & + & + \\
Inositol* $_{\text {Sorbitol* }}^{*}$ & - & - & - & - & - & - & - \\
Rhamnoz* & - & + & + & + & + & + & - \\
\hline Sakkaroz* & - & - & - & - & - & - & - \\
Melibioz* $^{*}$ & + & + & + & + & + & + & + \\
Amygdalin* & - & - & - & - & - & - & - \\
Arabinoz* & - & - & - & - & - & - & + \\
\hline
\end{tabular}

ONPG: $\beta$-Galaktosidaz, ADH: Arginin dihidrolaz, LDC: Lizin dekarboksilaz, ODC: Ornitin dekarboksilaz, TDA: Triptofan deaminaz, VP: Voges proskauer Reaksiyonu, *: 'den Asit Üretimi

\section{L. anguillarum Spesifik PCR ve Sekans Ana-}

lizi: Çalışmada fenotipik olarak identifiye edilen izolatlar genotipik olarak bakteriyel türlere özgü spesifik primerlerin kullanıldığ1 PCR yöntemi ile doğruland. Tüm izolatlar ve ATCC 14181 suşu $L$. anguillarum spesifik olan 429 bp bant verdiği saptandı (Şekil 1). Sekans analizi sonucu izolatlara ait amiB gen bölgesi dizgileri Genbank'a MK091482, MK091483, MK091484, MK091485, MK091486, MK091487 ve MK091488 kabul numaraları ile kaydedildi. Elde edilen sekansların GenBank veri tabanında yer alan DQ431190 erişim numaralı $L$. anguillarum Ami $\mathrm{B}(\mathrm{ami} \mathrm{B})$ gene, complete cds sekansıyla karşılaştırılması sonucu, izolatların en düşük \%96.1 en yüksek \%99.4 oranında benzer oldukları belirlendi.

Tablo 3. Çalışmada kullanılan L. anguillarum izolatlarının fenotipik özelliklerinin diğer araştırmacıların izolatlarıyla karşılaştırılması

\begin{tabular}{|c|c|c|c|c|}
\hline Fenotipik Özellikler & L. anguillarum 6 İzolat & Colorni ve ark., [8] & Austin ve Austin, [4] & Akaylı ve Durna, [1] \\
\hline Gr boyama & $-(6 / 6)$ & - & - & - \\
\hline Morfoloji & Çubuk eğri & Çubuk eğri & Çubuk eğri & Basil \\
\hline Haraket & $+(6 / 6)$ & + & + & + \\
\hline Stokrom oksidaz & $+(6 / 6)$ & + & + & + \\
\hline Katalaz & $+(6 / 6)$ & - & + & + \\
\hline Oksidasyon/Fermentasyon & $\mathrm{F}(6 / 6)$ & $\mathrm{F}$ & $\mathrm{F}$ & $\mathrm{F}$ \\
\hline $\mathrm{O} / 129$ & $+(6 / 6)$ & + & + & + \\
\hline Lizin dekarboksilaz & $-(5 / 6)$ & + & - & - \\
\hline Arginin dihidrolaz & $+(6 / 6)$ & - & + & + \\
\hline İndol & $+(6 / 6)$ & $+/-$ & + & + \\
\hline Üre & $-(6 / 6)$ & $+/-$ & - & - \\
\hline Jelatin & $+(6 / 6)$ & + & + & + \\
\hline $\mathrm{H}_{2} \mathrm{~S}$ & $-(6 / 6)$ & $+/-$ & - & $\cdot$ \\
\hline Metil Red & $+(4 / 6)$ & + & - & $\cdot$ \\
\hline Voges proskouer & $+(4 / 6)$ & - & + & + \\
\hline Sitrat & $+(6 / 6)$ & - & + & + \\
\hline$\% 0 \mathrm{NaCl}$ 'de üreme & $+(6 / 6)$ & - & - & - \\
\hline$\% 7 \mathrm{NaCl}^{\prime}$ de üreme & $+(6 / 6)$ & + & - & $\cdot$ \\
\hline $37^{\circ} \mathrm{C}$ üreme & $+(6 / 6)$ & $\cdot$ & + & + \\
\hline Glukoz & $+(6 / 6)$ & + & - & - \\
\hline Arabinoz & $-(5 / 6)$ & $+/-$ & + & - \\
\hline İnositol & $-(6 / 6)$ & - & - & - \\
\hline Sakkaroz & $+(6 / 6)$ & - & - & + \\
\hline Laktoz & $-(6 / 6)$ & $+/-$ & - & - \\
\hline Mannitol & $+(6 / 6)$ & $+/-$ & + & + \\
\hline
\end{tabular}

(+): Pozitif, (-): Negatif, (-): Yapılmadı 


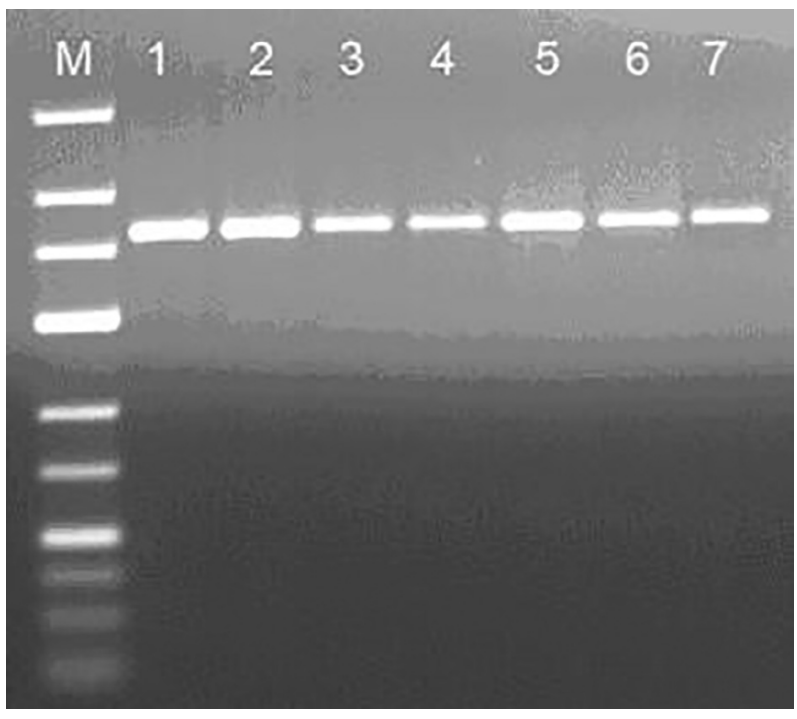

Şekil 1. L. anguillarum spesifik PCR, 429 bp. M; Marker $(25,50,75,100,150,200,300,400,500,700), 1-6$; L. anguillarum saha izolatları, 7; L. anguillarum ATCC 14181.

İzolatlar Arası Genetik İlişkinin Belirlenmesi: RAPD PCR analizi sonucunda L. anguillarum izolatlarının 6 farklı RAPD bant profili verdiği, izolatların \% 60 benzerlik katsayısına göre 1 tekli (unique) tip ve 1 küme (cluster) içerisinde gruplandığ 1 belirlendi. Buna göre ilk grupta sadece 4 numaralı izolatın yer aldığ 1 , ikinci grupta ise $1,2,3$, 5,6 ve 7 numaralı izolatların yer aldığ , ayrıca 2 ve 3 numaralı izolatların aynı RAPD bant paternine sahip olduğu belirlendi (Şekil 2).

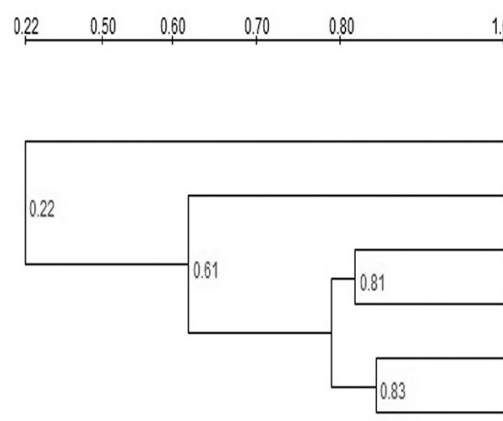
Isolate

No

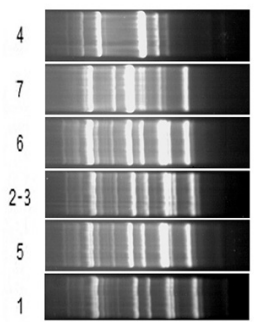

Şekil 2. L. anguillarum izolatlarının RAPD bant profilleri ve genotiplerinin filogenetik ağaçta gösterilmesi

İzolatların Antimikrobiyal Duyarlılık Profilleri: L. anguillarum izolatlarının çalışmada kullanılan dokuz farklı antibiyotiğe karşı değişik düzeyde antimikrobiyal aktiviteye sahip oldukları belirlendi
(Tablo 4). En yüksek direnç oranı neomisin ve linkomisin'e (\% 100), en düşük direnç oranı ise doksisiklin'e (\% 14.2) karş1 gözlendi.

Tablo 4. L. anguillarum izolatlarının antimikrobiyal duyarlılik profilleri

\begin{tabular}{lccccccc}
\hline \multirow{2}{*}{ Antibiyotikler } & \multicolumn{1}{c}{ L. anguillarum izolatları } \\
& $\mathbf{1}$ & $\mathbf{2}$ & $\mathbf{3}$ & $\mathbf{4}$ & $\mathbf{5}$ & $\mathbf{6}$ & $\mathbf{7}$ \\
\hline Gentamisin & R & S & S & S & S & S & R \\
Neomisin & R & R & R & R & R & R & R \\
Linkomisin & R & R & R & R & R & R & R \\
Oksitetrasiklin & R & I & R & R & S & I & I \\
Amoksisilin & R & S & R & R & R & R & R \\
Florfenikol & R & S & S & S & R & S & I \\
Trimetoprim- & R & S & S & S & S & S & R \\
sulfametoksazol & R & I & R & R & R & R & R \\
Eritromisin & R & S & S & I & I & S & I \\
Doksisiklin & r & & & & & &
\end{tabular}

\section{Tartışma ve Sonuç}

L. anguillarum, en az 28 farklı ülkede, toplamda 90'dan fazla akuatik organizma için patojenik olan bir bakteridir [16]. Etken Türkiye'de geniş bir coğrafik dağılıma sahip olup çipura deniz levreği, kırmızı porgy (Pagrus pagrus) ve Gökkuşağı alabalıklarından izole edilmiştir [24].

Genel olarak Vibriolarin identifikasyonu ve sınıflandırılması biyokimyasal testler kullanılarak yapılmaktadır [22]. Bakteriyel hastalık etkenlerinin fenotipik özelliklerinin belirlenmesinde ve teşhisinin yapılmasında en çok kullanılan yöntemlerden birisi de API 20E test kitleridir [2]. Ancak API test kitlerinin inkübasyon sıcaklıklarının balık patojenlerinin inkübasyon sıcaklıklarına uygun olmayışı, bu kitlerin balık patojenleri için kullanıldı ğında hatalı sonuçlar ortaya çıkmasına neden olmaktadır [5, 25]. Vibrio türlerinin fenotipik özelliklerinin ortaya konulmasında API 20E hızlı teşhis kitlerinin kullanıldığ 1 birçok çalışmada bulunmaktadır $[5,19,30$, 31]. Özellikle bu sistemin birbirine çok yakın iki tür olan $V$. anguillarum ile $V$. ordalii' yi kolaylıkla ayırt edebildiği rapor edilmiștir. Ancak sitrat testinde $V$. ordalii ve $V$. anguillarum izolatlarında büyük oranda değişkenlik görülmüş ve bu nedenle değerlendirme yapılırken sitrat testinin çıkartılması gerektiği bildirilmiştir. Yine aynı çalışmada $V$. anguillarum izolatları arasında bazı șeker testlerinde (Amygdalin ve 
Arabinoz) farklı sonuçların elde edildiği görülmüştür [14]. Yine bazı araştırmacılar ADH, sitrat, indol, VP ve sorbitol testlerinde izolatlar arasında fark11 sonuçların elde edildiğini bildirmişlerdir $[5,14$, $30,31]$. Benzer şekilde çalışmamızda API 20E test sonuçlarına göre çalıșmada kullanılan izolatlar arasinda $\mathrm{ADH}$, sitrat, amygdalin, arabinoz ve sorbitol testlerinde izolatlar arasında farkl1lıkların olduğu görülmüştür. Ek olarak Konvansiyonel mikrobiyolojik testler ile API 20E testi arasinda LDC, VP ve sitrat testlerinde farklı sonuçların olduğu belirlenmiştir. Bu çalışmada konvansiyonel mikrobiyolojik testler ile elde edilen sonuçlar diğer araştırmacıların bildirdiği sonuçlar ile karşılaştırıldığında $L$. anguillarum izolatlarının fenotipik olarak heterojen bir yapıya sahip olduğunu belirtilebilir (Tablo 4).

Apiweb veri tabanında $L$. anguillarum bulunmadığ 1 için sisteme girilen kodların $V$. fluvialis ve/ veya motil Aeromonas türlerinden biri olarak yanlış tanımlanabilmektedir [5]. Yapılan bir çalışmada $V$. anguillarum izolatlarının \% 66'ya yakın bir oranda A. hydrophila olarak identifiye edildiği bildirilmiştir [27]. Bu bağlamda son yıllarda L. anguillarum saptama metotları, tanı ve önleyici tedbirleri hızlı bir şekilde hayata geçirmek için kültür bazlı yöntemlerden uzaklaşmaya başlamıştır [16]. Çalışmamizda API ve konvansiyonel mikrobiyolojik test sonuçlarında görülen farkl11ıklar ve bu farkl11ıklara göre yapılabilecek olası yanlış değerlendirmelerden kaçınmak için izolatlar genetik olarak $A m i \mathrm{~B}$ genin kullanıldığı PCR ile konfirme edilmiş ve sonrasında PCR ürünlerinin sekans analizi yapılması ile sonuçlar konfirme edilmiştir.

Uzun yıllardır, kültür balıklarında bakteriyel enfeksiyonların tedavisinde antibiyotikler yaygin olarak kullanılmaktadır. Örneğin Norveç’te Vibrio salgınlarının önlenmesinde oksolinik asit ve florfenikol kullanılmaktadır [11]. Ülkemiz su ürünleri yetiștiriciliğinde Gıda Kontrol Genel Müdürlüğü verilerine göre balıklarda kullanılabilecek 40 adet ruhsatlı antibakteriyel ürün bulunmakta ve bu ürünlerin ise 5 farklı etken madde florfenikol, oksitetrasiklin $\mathrm{HCl}$, enrofloksasin, sülfadiazin-trimetoprim ve amoksisilin trihidrat içerdiği görülmektedir [12]. Ülkemizde L. anguillarum'un antibiyotik etkinliklerinin belirlendiği çalışmalar bulunmaktadır. Balta ve Balta, [5] Doğu Karadeniz Bölgesi'nden Gökkuşağı alabalıklarından elde ettikleri $L$. angu- illarum izolatlarının enrofloksasin, oksalinik asit ve florfenikol'e karşı, Tanrıkulu, [29] ise gökkuşağ alabalıklarından izole ettiği 12 izolatın amoksisilin ve trimetoprim-sulfadiazine karşı duyarlı olduklarını belirlemişlerdir. Bu çalışmada elde edilen test sonuçlarına göre hastalığın tedavisinde florfenikol veya trimetoprim-sulfametoksazol'den birinin kullanılmasının uygun olacağ

L. anguillarum izolatları arasındaki genetik ilişkiler farklı random primerlerin kullanıldığg RAPD PCR metodu ile belirlenmiştir. Vaseeharan ve ark., [34] OPP6, OPP9, OPAX5, OPAX18 ve OPX1 primerlerini kullandıkları çalışmalarında izolatların unique tipte RAPD profili sergilediklerini dolayısıyla genetik olarak heterojen bir yapıda olduklarını ortaya koymuşlardır. OPV-12 ve OPN-08 kullanıldığ 1 başka bir çalışmada ise $L$. anguillarum izolatları 5 genotipe ayrılmıştır. Gökkuşağı alabalıklardan elde edilen izolatların levrek balıkları ve sedimentten izole edilen izolatlar ile aynı genogrupta yer aldığını belirlemişlerdir [10]. Bu çalışmada RAPD PCR metodunda kullanılan M13 primerinin L. anguillarum izolatların genotiplendirmesinde kullanılabilir olduğu ancak diğer araştırmacılardan farklı olarak izolatların genetik olarak homojen bir yapıda olduğu belirlenmiştir. Bu farklılığın izolat sayısına ve coğrafi dağılıma bağlı olabileceği düşünülmüştür.

Bu çalışma ile L. anguillarum izolatların identifikasyonunda konvansiyonel mikrobiyolojik metotlar ile API 20E test kitleri arasında farklı sonuçların görülebileceği, dolayısıyla tür identifikasyonunun moleküler çalışmalar ile desteklenmesi gerektiği, izolatlar arası klonal ilişkilerin belirlenmesinde M13 primerinin kullanıldığı RAPD PCR metodunun hızlı ve güvenilir bir sonuç verdiği ortaya konulmuștur.

\section{Teșekkür}

Bu çalıșma, 2'inci Uluslararası Veteriner Mikrobiyoloji Kongresi'nde sözlü bildiri olarak sunulmuştur.

\section{Kaynaklar}

1. Akayl1 T, Durna M, (2017). Kültür Levrek (D. labrax) Balıklarından izole edilen Vibrio anguillarum izolatlarının karakterizasyonu. Kocatepe Vet J. 10(3), 134-141. 
2. Altun S, Kubilay A, Diler O, (2010). Yersinia ruckeri suşlarının fenotipik ve serolojik özelliklerinin incelenmesi. Kafkas Univ Vet Fak Derg.16(Suppl B), 223-229.

3. Austin B, Alsina M, Austin DA, Blanch AR, Grimont F, Grimont PAD, Jofre J, Koblavi S, Larsen JL, Pedersen K, Tiainen T, Verdonck L, Swings J, (1995). Identification and typing of Vibrio anguillarum: a comparison of different methods. Syst Appl Microbiol. 18, 285-302.

4. Austin B, Austin DA, (1993). Bacterial fish pathogens disease of farmed and wild fish, Second edition. Chichester, England, Ellis Horwood. p.269-270.

5. Balta F, Balta ZD, (2017). Doğu Karadeniz'de yetiştiriciliği yapılan gökkuşă̆ı alabalıkları (Oncorhynchus mykiss)'ndan izole edilen Vibrio anguillarum suşlarının serotiplendirilmesi, genetik karakterizasyonu ve antimikrobiyal duyarlılı̆̆ının belirlenmesi. Ankara Üniv Vet Fak Derg. 64, 321-328.

6. Beaz-Hidalgo R, Lopez-Romalde S, Toranzo AE., Romalde JL, (2008). Polymerase Chain Reaction amplification of Repetitive Intergenic Consensus and Repetitive Extragenic Palindromic Sequences for molecular typing of Pseudomonas anguilliseptica and Aeromonas salmonicida. J Aquat Anim Health. 20, 75-85.

7. CLSI, (2014). Performance standards for antimicrobial susceptibility testing. Twenty-Fourth Informational Supplement. Clinical Laboratory Standards Institute, Wayne, USA, M100-S24, 230s.

8. Colorni A, Paperna I, Gordin H, (1981). Bacterial infections in gilt-head sea bream Sparus aurata cultured at Elat. Aquaculture, 23, 257-267.

9. Cunningham CO, (2002). Molecular diagnosis of fish and shellfish diseases: present status and potential use in disease control. Aquaculture. 206, 19-55.

10. Frans I, Dierckens K, Crauwels S, Assche AV, Leisner J, Larsen MH, Michiels CW, Willems KA, Lievens B, Bossier P, Rediers H, (2013). Does virulence assessment of Vibrio anguillarum using Sea Bass (Dicentrarchus labrax) Larvae correspond with genotypic and phenotypic characterization? Plos One. 8(8), e70477.

11. Frans I, Michiels CW, Bossier P, Willems KA, Lievens B, Rediers H, (2011). Vibrio anguillarum as a fish pathogen: virulence factors, diagnosis and prevention. J Fish Dis. 34, 643-661.

12. Gıda Tarım ve Hayvancılık Bakanlığı. İyi Üretim Uygulamaları Sertifikası (GMP) Bakanlığımızca Verilmiş veya Kabul Edilmiş Pazarlama İzinli Veteriner Biyolojik Ürünler. https://www.tarim.gov.tr/Konular/VeterinerHizmetleri/Veteriner-Saglik-Urunleri. İnternet Erişimi: 15.03.2018.

13. Gonzalez SF, Osorio CR, Santos Y, (2003). Development of a PCR-based method for the detection of Listonella anguillarum in fish tissue and blood samples. Dis Aquat Org. 55, 109-115.p

14. Grisez L. Ceusters R. Ollevier F, (1991). The use of API $20 E$ for the identification of Vibrio anguillarum and V. ordalii. J Fish Dis. 14, 359-365.
15. Harrell LW, Novoty AJ, Schiewe MH, Hodgins HO, (1976). Isolation and description of two vibrios pathogenic to Pacific salmon in Puget Sound, Washington. Fish Bullet. 74, 447-449.

16. Hickey ME, Lee J-L, (2018). A comprehensive review of Vibrio (Listonella) anguillarum: ecology, pathology and prevention. Rev Aquacult. 10, 585-610.

17. Hong GE, Kim DG, Bae JY, Ahn SH, Bai SC, Kong IS, (2007). Species-specific PCR detection of the fish pathogen, Vibrio anguillarum, using the amiB gene, which encodes $N$-acetylmuramoyl-L-alanine amidase. FEMS Microbiol Lett. 269, 201-206.

18. Huang Y, Runge M, Michael GB, Schwarz S, Jung A, Steinhagen D, (2013). Biochemical and molecular heterogeneity among isolates of Yersinia ruckeri from rainbow trout (Oncorhynchus mykiss, Walbaum) in north west Germany. BMC Vet Res. 9, 215

19. Korun J, Gokoglu M, (2007). Listonella anguillarum isolated from hatchery cultured red porgy Pagrus pagrus in Turkey. J Anim Vet Adv. 6, 823-827.

20. Kuhn I, Austin DA, Austin B, Blanch AR, Grimont PAD, Jofre J, Koblavi S, Larsen JL, Mollby R, Pedersen K, Tiainen T, Verdonck L, Swings J, (1996). Diversity of Vibrio anguillarum isolates from different geographical and biological habitats, determined by the use of a combination of eight different typing methods. Syst Appl Microbiol. 19, 442-450.

21. MacDonell MT, Colwell RR, (1985). Phylogeny of the Vibrionaceae, and recommendation for two new genera, Listonella and Shewanella. Syst Appl Microbiol. 6, 171182.

22. Noguerola I. Blanch AR, (2008). Identification of Vibrio spp. with a set of dichotomous keys. J Appl Microbiol. 105, 175-185.

23. Onuk EE, Çiftci A, Fındık A, Çiftci G, Altun S, Balta F, Özer S, Çoban AY, (2011). Phenotypic and molecular characterization of Yersinia ruckeri isolates from Rainbow Trout (Oncorhynchus mykiss, Walbaum, 1792) in Turkey. Berl Munch Tierarztl Wochenschr. 124 (7-8), 320-328.

24. Öztürk RÇ, Altınok İ, (2014). Bacterial and viral fish diseases in Turkey. Turk J of Fish Aquat Sci. 14, 275-297.

25. Popovic TN, Coz-Rakovac R, Strunjak-Perovic I, (2007). Commercial phenotypic tests (API 20E) in diagnosis of fish bacteria: a review. Vet Med. 52(2), 49-53.

26. Ravelo C, Magarinos B, Lopez-Ramade S, Toranzo AE, Romalde JL, (2003). Molecular fingerprinting of fishpathogenic Lactococcus garvieae strains by Random Amplified Polymorphic DNA Analysis. J Clin Microbiol. 41(2), 751-756.

27. Santos Y, Romalde JL, Bandín I, Magarinos B, Nunez S, Barja JL, Toranzo AE, (1993). Usefulness of the API-20E system for the identification of bacterial fish pathogens. Aquaculture. 116(2-3), 111-120.

28. Schiewe MH, Trust TJ, Crosa JH, (1981). Vibrio ordalii sp.nov.: a causative agent of vibriosis in fish. Curr Microbiol. 6, 343-348. 
29. Tanrikul TT, (2007). Vibriosis as an epizootic disease of rainbow trout (Onchorhynchus mykiss) in Turkey. Pak J Biol Sci. 10, 1733-1737.

30. Tanrikul TT, Cagirgan H, Toksen E, (2004). Levreklerden (Dicentrarchus labrax L., 1758) izole edilen vibrio türlerinin API $20 E$ yöntemiyle identifikasyonu. EÜ Su Ürünleri Dergisi. 21, 243-247.

31. Tanrikul TT, Gultepe N, (2011). Mix infections in rainbow trout (Oncorhynchus mykiss, Walbaum) Lactococcus garvieae and Vibrio anguillarum O1. J Anim Vet Adv. 10, 1019-1023.

32. Tekerekoglu MS, Ay S, Otlu B, Çiçek A, Kayabaş Ü, Durmaz R, (2007). Molecular epidemiology of methicil- lin-resistant Staphylococcus aureus isolates from clinical specimens of patients with nosocomial infection: are there unnoticed silent outbreaks? New Microbiol. 30, 131-137.

33. Versalovic J, Koeuth T, Lupski R, (1991). Distribution of repetitive DNA sequences in eubacteria and application to fingerprinting of bacterial genomes. Nuc Acid Res. 19(24), 6823-6831.

34. Vaseeharan B, Hussian MR, Chen JC, (2008). RpoN gene, $R A P D$ profile, antimicrobial resistance and plasmids of Vibrio anguillarum isolates from vibriosis infected Penaeus monodon. Lett Appl Microbiol. 47, 380-385.

35. Xiao P, Mo ZL, Mao YX, Wang CL, Zou YX, Li J, (2009). Detection of Vibrio anguillarum by PCR amplification of the empA gene. J Fish Dis. 32, 293-296. 